\title{
Melting of Amphibolite Xenolith Included in Peridotite of the Hidaka Metamorphic Belt, Hokkaido
}

\author{
Michio Tagiri ${ }^{1}$, Hideo Suzuki ${ }^{2}$, Kenji Suzuki ${ }^{3}$,

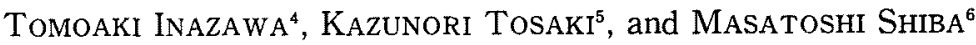 \\ ${ }^{1}$ Department of Earth Sciences, Ibaraki University, \\ Mito 310, Japan \\ ${ }^{2}$ Chishitsu Kogaku Company Ltd., Shinjuku-ku 160, Japan \\ ${ }^{3}$ Shonan-Takayanagi High School, Higashikatsushika-gun, \\ Shonan-machi 277, Japan \\ ${ }^{4}$ Geoscience Company Ltd., Bunkyo 113, Japan \\ ${ }^{5}$ Ichijo Junior High School, Utsunomiya 320, Jatan \\ ${ }^{6}$ Department of Earth Sciences, Hirosaki University, \\ Hirosaki 036, Japan
}

\begin{abstract}
A fine-grained amphibolite xenolith was found in the Nikanbetsu peridotite body in the Hidaka metamorphic belt, Hokkaido, Japan. A thin crust of coarse-grained gabbro surrounds the xenolith cutting across the foliation of the amphibolite xenolith which is composed of kaersutite-pargasite, plagioclase, ilmenite, phlogopite and rutile. The gabbro crust consists of aluminous clinopyroxene, kaersutite-pargasite, plagioclase and ilmenite with minor hornblende, cummingtonite, phlogopite, olivine and spinel. The host rock is a plagioclase-spinel peridotite.

Major element chemical compositions of the amphibolite xenolith and the gabbro crust are similar to each other, suggesting that the gabbro crust is a melting product of the amphibolite xenolith. REE contents are also similar to each other, but higher in the gabbro crust than in the amphibolite xenolith. The bulk rock partition coefficients of REE between the xenolith and the gabbro melt suggest $35-40 \%$ melting for the production of the gabbro crust, whereas the structure and chemistry of the xenolith indicate a total melting of xenolith's rim, suggesting a migration of REE from the xenolith's interior to the melt.

The xenolith was included in a hot solid peridotite mass through solid intrusion of peridotites into the lower crust. During and after melting, $\mathrm{Mg}-\mathrm{Fe}$ diffusion proceeded between the gabbro crust and the peridotites, and reached into about $1 \mathrm{~cm}$ depth of the peridotites. Based on the solid diffusion model on a polycrystalline olivine, $0.2 \mathrm{My}$ is estimated for the duration of heating at minimum melting temperatures (about $900^{\circ} \mathrm{C}$ ) of the gabbro. This rapid increase of temperature by the intrusion of hot solid peridotites may cause the lower part of the Main Zone to partially melt.
\end{abstract}

\section{Introduction}

The Hidaka belt of Hokkaido, Japan, is divided into two parts: the Western Zone and the Main Zone (Komatsu et al., 1982). The former consists of meta-ophiolite (Miyashita, 1983), while the latter of various kinds of plutonic igneous and metamorphic rocks, rang. ing from the greenschist to the granulite facies in grade (Osanai, 1985; Osanai et al., 1986; Shiba, 1988). The Main zone includes also many kinds of peridotite bodies closely associated with metamorphics.

Migmatites occur widely in the granulite facies area (Osanai, 1985), between plutonic migmatites and metamorphics, and very rarely

(Manuscript received, July 6,1988;

accepted for publication, August 4, 1988) 


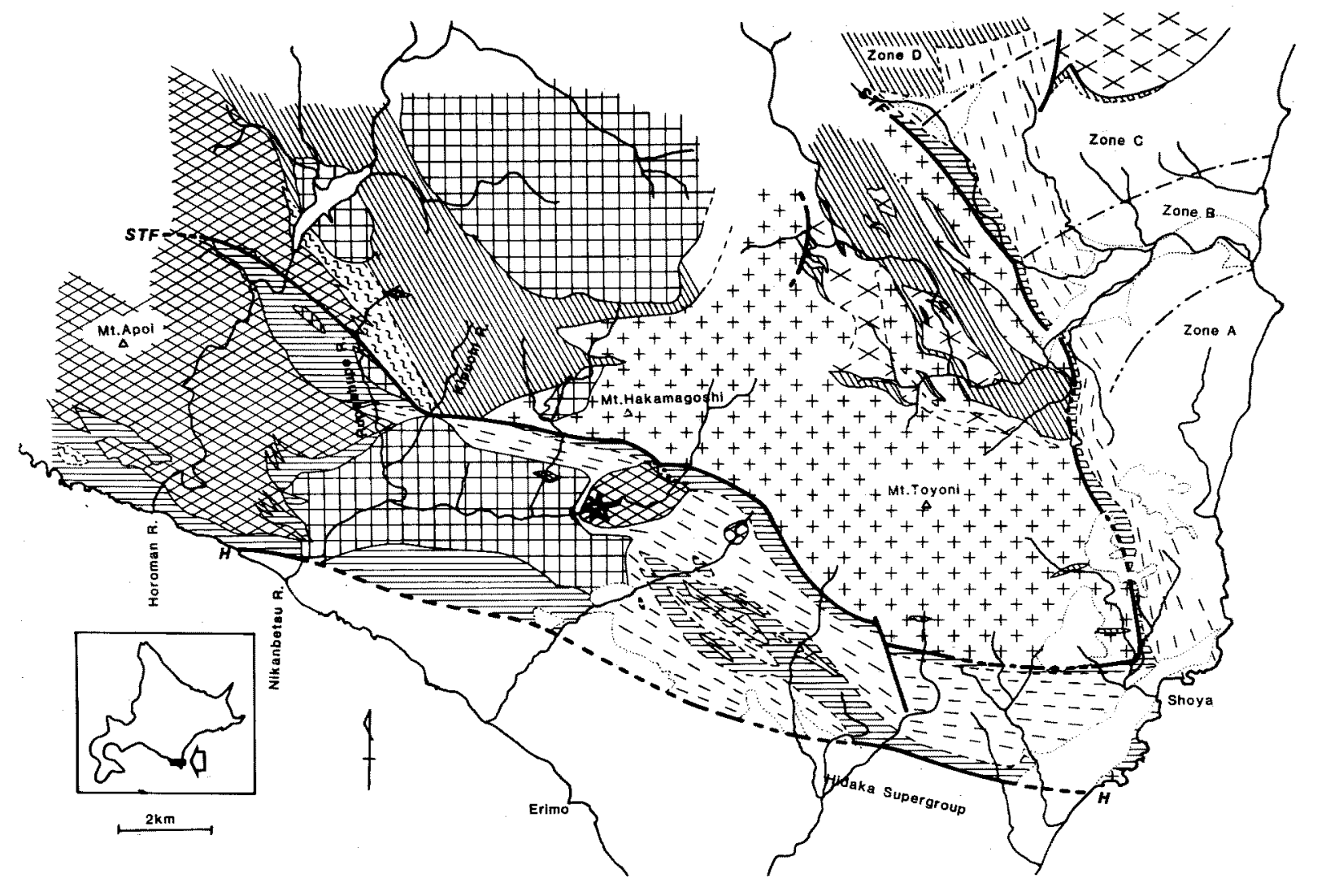

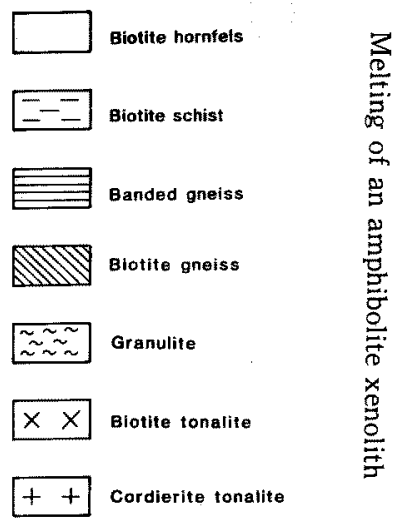

曲 Gabbro-diorite

Peridotite

Fig. 1. Generalized geological map of the Southmost Hidaka Mts. 
between peridotites and metamorphics. Recently we found a gabbroic rock surrounding amphibolite included in a peridotite mass, which gives us a detailed information for the process of partial melting.

\section{Outline of Geology}

A generalized geologic map of the southmost Hidaka Mts. area is presented in Fig. 1. The eastern part of the area was mapped by Shiba (1988), and the western part by M. Tagiri, H. Suzuki, K. Suzuki, T. Inazawa and K. Tosaki of Ibaraki University. According to Shiba (1988), the lowest metamorphic grade zone is in the southeastern district near Shoya. The rocks were derived from mudstones and sandstones of the Mesozoic Nakanogawa Supergroup (Kontani, 1978). In the eastern part., the metamorphic grade increases northward, and reaches to the higher amphibolite facies in Zone D of Shiba (1988).

The metamorphic rocks along the SaruruToyoni-Furukawa shear zone (STF-STF) are strongly mylonitized by the upthrust of the Central Metamorphic and Igneous Composite Mass (CMIC Mass) which consists of highgrade metamorphics including granulites, migmatites, cordierite tonalite, gabbro-diorites and peridotites. At the time of upthrusting, the CMIC Mass was hot enough to make a thermal aureole in the zones A, B and C of Shiba (1988), though it is not recognized clearly in the southern marginal mylonite zone between the STF and the Horoizumi shear zone $(\mathrm{H}-\mathrm{H})$. Peridotite bodies and higher-grade metamorphics including granulites crop out frequently in the western part of the southern marginal mylonite zone. It is difficult to make a metamorphic zonal map in the southern marginal mylonite zone because of strong deformation and alteration.

Lower-grade metamorphic rocks of the CMIC Mass have similar mineral assemblages to those of Zone D of Shiba (1988) outside of the mass. Cordierite tonalite are intruded into the central part of the metamorphic rock terrain. Furthermore, in many places pelitic and basic metamorphic rocks are migmatized (Fig. 1).

Fig. 2 shows the intrusion sequence of igneous rocks in this area. The rocks comprise peridotite, gabbro-diorite, tonalite and basalt. The peridotites have a remarkable layered structure consisting of dunite, spinel lherzolite, plagioclase lherzolite and gabbro (Niida, 1984). They are penetrated by gabbro-diorite dikes in the middle of the Rupeshupe River, and in a fault contact with mylonitic granulites at the Horoman reservoir. An amphibolite xenolith was found in the peridotite mass in the middle of Nikanbetsu River.

The gabbro-diorites are heterogeneous, and are divided into five types such as olivine gabbro, pyroxene gabbro, hornblende gabbro, hornblende diorite and cordierite bearing orthopyroxene diorite. The latter two include many metamorphic blocks and xenoliths, and in part, porphyritic plagioclase phenocrysts. The gabbro-diorites are frequently penetrated by

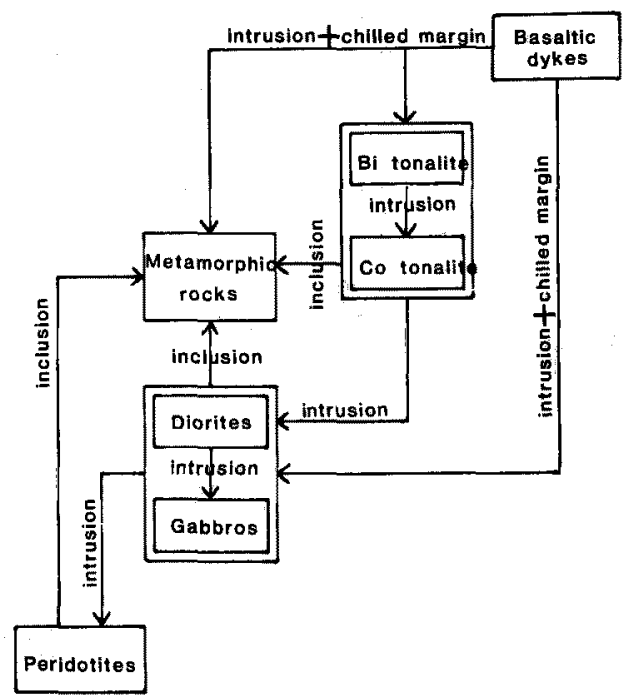

Fig. 2. The intrusion sequence of plutonic igneous rocks. 
tonalites. The tonalites consist of cordierite tonalites and biotite tonalites. The former contain many metamorphic rock xenoliths, and are intruded so frequently into the metamorphic strata that migmatitic features are observed in many outcrops. Biotite tonalites are intruded into the cordierite tonalites (Shiba, 1988). After all, the basaltic dikes with a chilled margin are intruded into metamorphic and igneous rocks of the area.

\section{Amphibolite Xenolith}

An amphibolite xenolith was found in the peridotite body of the Nikanbetsu River. The host peridotite is a plagioclase $(\mathrm{An}=65)$-spinel therzolite. The xenolith is an ellipsoidal disk, $20 \times 10 \times 3 \mathrm{~cm}$ in size. Its outline crosscuts the layering structure of the host peridotite (Fig. 3). Medium- to coarse-grained gabbroic crust, 3 to $5 \mathrm{~mm}$ in width, surrounds it (Fig. 4). The boundary betweeen the xenolith and the crust is gradual, but that between the latter and the host peridotite is sharp (Fig. 4). Xenolith amphibolite is fine-grained, foliated and composed of kaersutite-pargasite, plagioclase $(\mathrm{An}=50)$, phlogopite and ilmenite with subordinate rutile. On the other hand, the gabbroic crust consists of aluminous clinopyroxene, kaersutite-pargasite, plagioclase $(\mathrm{An}=50)$, and ilmenite with minor hornblende, cummingtonite, phlogopite,

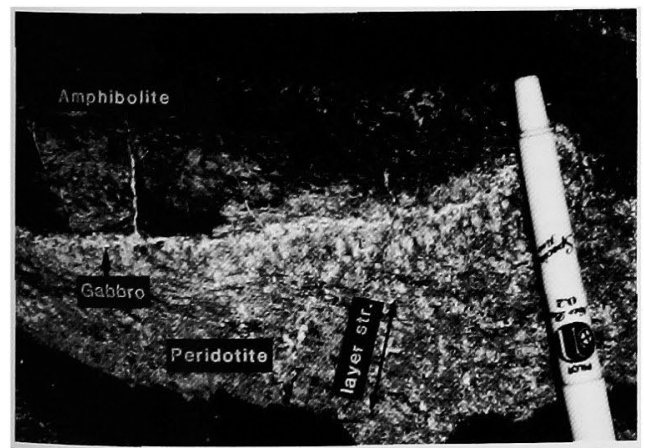

Fig. 3. Occurrence of the amphibolite xenolith. An arrow indicates the direction of layering in the host peridotite.

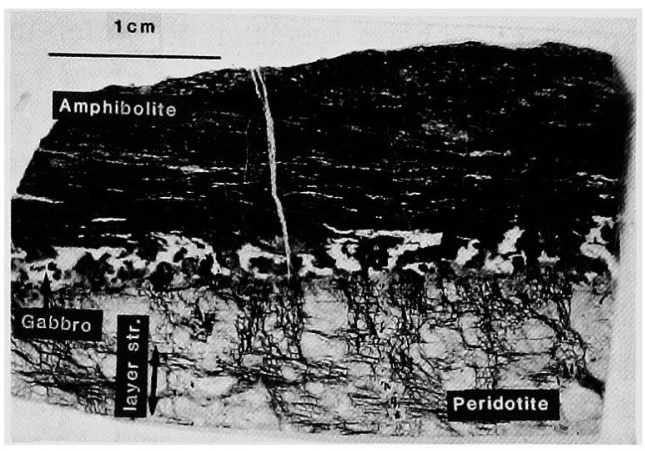

Fig. 4. Thin section photograph of the amphibolite xenolith. $\mathrm{A}=$ amphibolite, $\mathrm{P}=$ peridotite.

olivine and spinel.

Chemical compositions of the amphibolite, gabbro crust and peridotites are presented in Table 1. The analysed samples were obtained

Table 1. Chemical compositions of bulk rocks

\begin{tabular}{|c|c|c|c|c|}
\hline$w t \%$ & Amphibolite & Gabbro & Peridotite -1 & Peridotite-2 \\
\hline $\mathrm{SiO}_{2}$ & 41.58 & 40.99 & 42.03 & 40.74 \\
\hline $\mathrm{TiO}_{2}$ & 6.45 & 6.51 & 0.27 & 0.08 \\
\hline $\mathrm{AL}_{2}{ }^{0} 3$ & 16.99 & 13.99 & 2.83 & 2.50 \\
\hline $\mathrm{Fe}_{2}{ }^{0} 3$ & 1.93 & 1.69 & 2.44 & 3.17 \\
\hline $\mathrm{F} e \mathrm{O}$ & 8.86 & 9.14 & 10.88 & 5.32 \\
\hline $\mathrm{MnO}$ & 0.14 & 0.15 & 0.21 & 0.13 \\
\hline $\mathrm{MgO}$ & 9.30 & 12.52 & 34.33 & 36.77 \\
\hline $\mathrm{CaO}$ & 9.51 & 10.65 & 2.53 & 1.60 \\
\hline $\mathrm{Na}_{2} \mathrm{O}$ & 3.26 & 2.17 & 0.44 & 0.17 \\
\hline $\mathrm{k}_{2} \mathrm{O}$ & 0.21 & 0.16 & 0.04 & 0.02 \\
\hline $\mathrm{H}_{2} \mathrm{O}+$ & 1.69 & 1.93 & 3.40 & 8.55 \\
\hline $\mathrm{H}_{2} \mathrm{O}^{-}$ & 0.08 & 0.10 & 0.08 & 0.30 \\
\hline $\mathrm{P}_{2} \mathrm{O}_{5}$ & 0.01 & 0.01 & 0.01 & 0.01 \\
\hline $\mathrm{NiO}$ & $-\cdots$ & --- & 0.13 & 0.25 \\
\hline $\mathrm{Cr}_{2} \mathrm{O}_{3}$ & -- & $-\cdots$ & 0.38 & 0.39 \\
\hline \multicolumn{5}{|l|}{$\frac{2}{p p m}$} \\
\hline$B a$ & 111 & 88 & 23 & 38 \\
\hline $\mathrm{Cu}$ & 112 & 207 & 42 & 13 \\
\hline $\mathrm{Nb}$ & 25 & 24 & 5 & 3 \\
\hline Sc & 36 & 58 & 13 & 9 \\
\hline sr & 726 & 883 & 53 & 44 \\
\hline v & 611 & 556 & 61 & 40 \\
\hline $\mathrm{zn}$ & 76 & 84 & 110 & 68 \\
\hline $\mathrm{Zr}$ & 38 & 82 & 18 & 25 \\
\hline La & 1.9 & 2.2 & 0.0 & 0.0 \\
\hline $\mathrm{Ce}$ & 7 & 9 & 1 & 1 \\
\hline $\mathrm{Nd}$ & 5.6 & 9.2 & 0.3 & 0.0 \\
\hline S m & 1.27 & 2.91 & 0.0 & 0.0 \\
\hline Eu & 1.31 & 1.55 & 0.18 & 0.09 \\
\hline Gd & 2.4 & 4.4 & 0.7 & 0.7 \\
\hline Dy & 2.42 & 4.49 & 0.52 & 0.20 \\
\hline Er & 1.55 & 3.75 & 0.81 & 1.03 \\
\hline$Y b$ & 1.06 & 1.96 & 0.29 & 0.12 \\
\hline Lu & 0.10 & 0.22 & 0.0 & 0.0 \\
\hline$Y$ & 11.25 & 20.7 & 2.7 & 1.3 \\
\hline
\end{tabular}


by cutting the hand specimen to wafer-thin plates. Peridotite- 1 is a portion of about $1 \mathrm{~cm}$ width in contact with the gabbro crust and Peridotite-2 lies outside Peridotite-1. The gabbro has a similar chemical composition to that of amphibolite. $\mathrm{TiO}_{2}$ content of the amphibolite is enormously high. Among these rocks, $\mathrm{SiO}_{2}, \mathrm{MgO}$ and $\mathrm{H}_{2} \mathrm{O}$ contents increase, and $\mathrm{Al}_{2} \mathrm{O}_{3}, \mathrm{Na}_{2} \mathrm{O}$ and $\mathrm{K}_{2} \mathrm{O}$ contents decrease from the amphibolite towards Peridotite-2. In contrast to these components, total $\mathrm{Fe}$ content becomes maximum in Peridotite-1. $\mathrm{CaO}$ and $\mathrm{TiO}_{2}$ contents of the amphibolite are similar to those of the gabbro crust, but Peridotites 1 and 2 are poor in them. The chemical change in these rocks would be explained by two models. One is the melting of the amphibolite xenolith, and the other the chemical interaction by diffusion between the gabbro crust and Peridotite-2.

Chemical compositions of amphiboles, pyroxenes, olivine, spinels and phlogopite were determined by means of an EPMA, and presented in Table 2. Chemical compositions of $\mathrm{Ca}^{-}$ amphiboles are plotted on the diagrams for the nomenclature of $\mathrm{Ca}$-amphiboles by Leake (1978) (Fig. 5). Ca-amphiboles in the amphibolite xenolith and the gabbro crust show a zonal structure similar to each other, that is, the core is red-brown kaersutite, the mantle brown pargasite and the rim pale green hornblende. The kaersutite core exsolves many fine-grained needles of rutile along the crystal axes. Pargasites in the amphibolite and the gabbro are poorer in $\mathrm{Mg}$ than those in the host peridotite. Fig. 6 shows Ti versus $\mathrm{Al}$ contents of amphiboles from the xenolith and the $\mathrm{Ho}$ roman ultramafic complex. Chemical compositions of the amphiboles in the xenolith range from those of crustal amphiboles to those of mantle amphiboles (Gamble and Kyle, 1987). The composition of amphibole core is plotted in the field of crustal amphiboles. On the other hand, those of amphibole rim lie in the field of

Table 2. Chemical compositions of representative minerals

\begin{tabular}{|c|c|c|c|c|c|c|c|c|c|c|}
\hline & \multicolumn{3}{|c|}{ Amphibole } & \multicolumn{2}{|c|}{$C p x$} & \multirow{2}{*}{$\operatorname{lop}_{6}$} & \multirow{2}{*}{$\begin{array}{r}01 \\
7\end{array}$} & \multirow{2}{*}{$\begin{array}{c}\mathrm{Phl} \\
8\end{array}$} & \multicolumn{2}{|l|}{ So } \\
\hline & 1 & 2 & 3 & 4 & 5 & & & & 9 & 10 \\
\hline $\mathrm{SiO}_{2}$ & 40.50 & 42.24 & 41.47 & 48.15 & 49.70 & 54.53 & 38.54 & 38.24 & 0.03 & 0.05 \\
\hline $\mathrm{TiO}_{2}$ & 6.01 & 2.42 & 4.77 & 2.00 & 0.78 & 0.17 & n.d. & 1.18 & 0.00 & 0.44 \\
\hline $\mathrm{Al}_{2} \mathrm{O}_{3}$ & 13.50 & 15.24 & 13.18 & 6.57 & 5.51 & 2.32 & n.d. & 19.49 & 64.46 & 34.41 \\
\hline $\mathrm{Cr}_{2} \mathrm{O}_{3}$ & 0.53 & 0.02 & 0.05 & 0.03 & 1.02 & 0.32 & $n . d$. & 0.02 & 0.00 & 27.91 \\
\hline$F \in O$ & 8.38 & 10.93 & 11.58 & 6.98 & 5.56 & 9.14 & 17.58 & 9.57 & 23.93 & 28.21 \\
\hline MnO & 0.12 & 0.06 & 0.11 & 0.18 & 0.18 & 0.28 & 0.30 & 0.08 & 0.15 & 0.26 \\
\hline NiO & 0.00 & 0.05 & 0.07 & 0.08 & 0.00 & 0.00 & 0.29 & 0.17 & 0.13 & 0.22 \\
\hline $\mathrm{MgO}$ & 15.35 & 12.73 & 12.40 & 13.26 & 15.07 & 31.54 & 43.14 & 18.98 & 12.93 & 8.18 \\
\hline $\mathrm{CaO}$ & 11.29 & 11.73 & 11.45 & 21.17 & 21.07 & 0.93 & 0.00 & 0.06 & 0.02 & 0.05 \\
\hline $\mathrm{Na}_{2}{ }^{\circ}$ & 2.34 & 2.49 & 2.26 & 0.71 & 0.73 & 0.04 & n.o. & 1.32 & $n . d$. & n.d. \\
\hline $\mathrm{K}_{2} \mathrm{O}$ & 0.68 & 0.45 & 0.61 & 0.00 & 0.00 & 0.00 & n.d. & 7.27 & n.a. & n.d. \\
\hline Total & 98.70 & 98.36 & 97.95 & 99.13 & 99.62 & 99.27 & 99.85 & 96.38 & 101.65 & 99.73 \\
\hline si & 5.847 & 6.127 & 6.089 & 1.804 & 1.840 & 1.928 & 0.985 & 2.957 & 0.001 & 0.002 \\
\hline$A L^{I V}$ & 2.153 & 1.873 & 1.911 & 0.196 & 0.160 & 0.072 & n.d. & 1.043 & & \\
\hline$A L^{V I}$ & 0.144 & 0.733 & 0.370 & 0.094 & 0.080 & 0.025 & $n . d$. & 0.732 & 1.970 & 1.223 \\
\hline $\mathrm{T} \mathbf{i}$ & 0.652 & 0.264 & 0.527 & 0.056 & 0.022 & 0.005 & n.d. & 0.069 & $0 . a$ & 0.010 \\
\hline $\mathrm{Cr}_{\mathrm{r}}$ & 0.060 & 0.002 & 0.006 & 0.001 & 0.030 & 0.009 & n.d. & 0.001 & n.d. & 0.665 \\
\hline $\mathrm{Fe}^{3+}$ & $n \cdot d$ & $n . d$. & $n . d$. & $n . d$. & $n . d$. & $n . d$. & n.d. & $n . d$. & 0.030 & 0.097 \\
\hline $\mathrm{Fe}^{2+}$ & 1.012 & 1.326 & 1.422 & 0.219 & 0.172 & 0.270 & 0.376 & 0.619 & 0.489 & 0.615 \\
\hline $\mathrm{Mn}$ & 0.035 & 0.007 & 0.014 & 0.006 & 0.006 & 0.008 & 0.006 & 0.005 & 0.003 & 0.007 \\
\hline $\mathrm{Ni}$ & n.d. & 0.006 & 0.008 & 0.002 & $n . d$. & $n . d$. & 0.006 & 0.011 & 0.003 & 0.005 \\
\hline Mg & 3.303 & 2.752 & 2.714 & 0.740 & 0.832 & 1.662 & 1.643 & 2.187 & 0.505 & 0.372 \\
\hline $\mathrm{Ca}$ & 1.746 & 1.823 & 1.801 & 0.850 & 0.836 & 0.035 & n.d. & 0.005 & 0.001 & 0.002 \\
\hline $\mathrm{Na}$ & 0.655 & 0.700 & 0.643 & 0.052 & 0.052 & 0.003 & $n . d$. & 0.198 & $\pi . d$. & $n . d$. \\
\hline k & 0.125 & 0.083 & 0.114 & n.d. & m. o. & $n \cdot d$. & n.d. & $0.71 ?$ & $n . d$. & n.d. \\
\hline
\end{tabular}


$\mathrm{Mg} /(\mathrm{Mg}+\mathrm{Fe})$
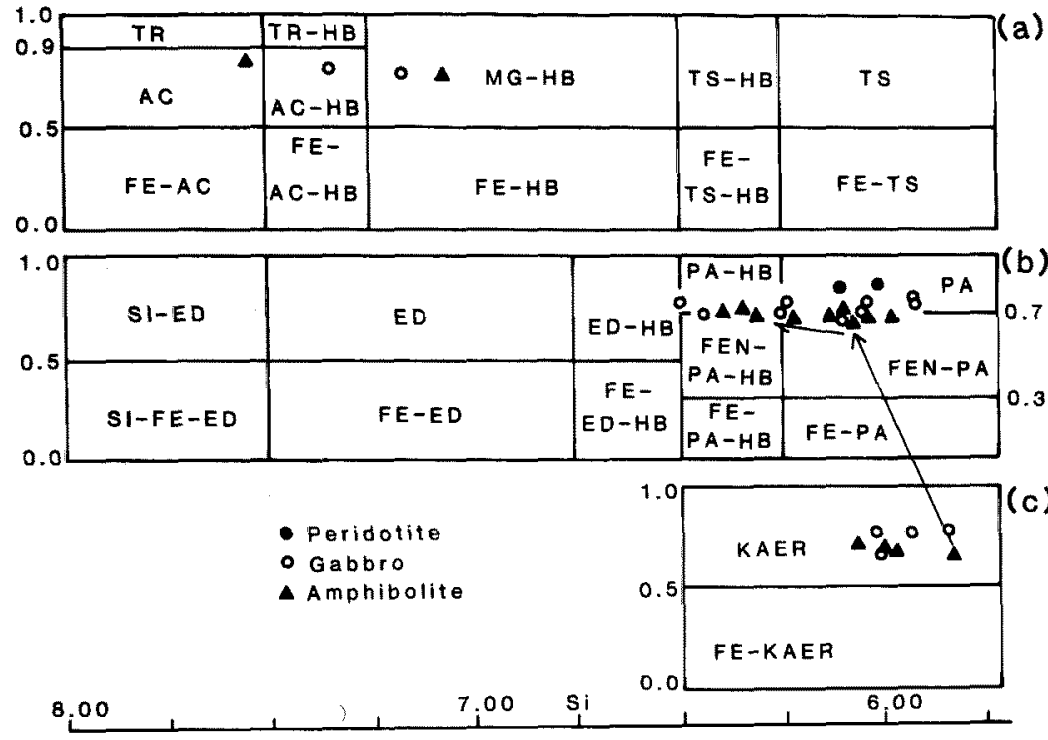

Fig. 5. Chemical classification of the amphiboles.

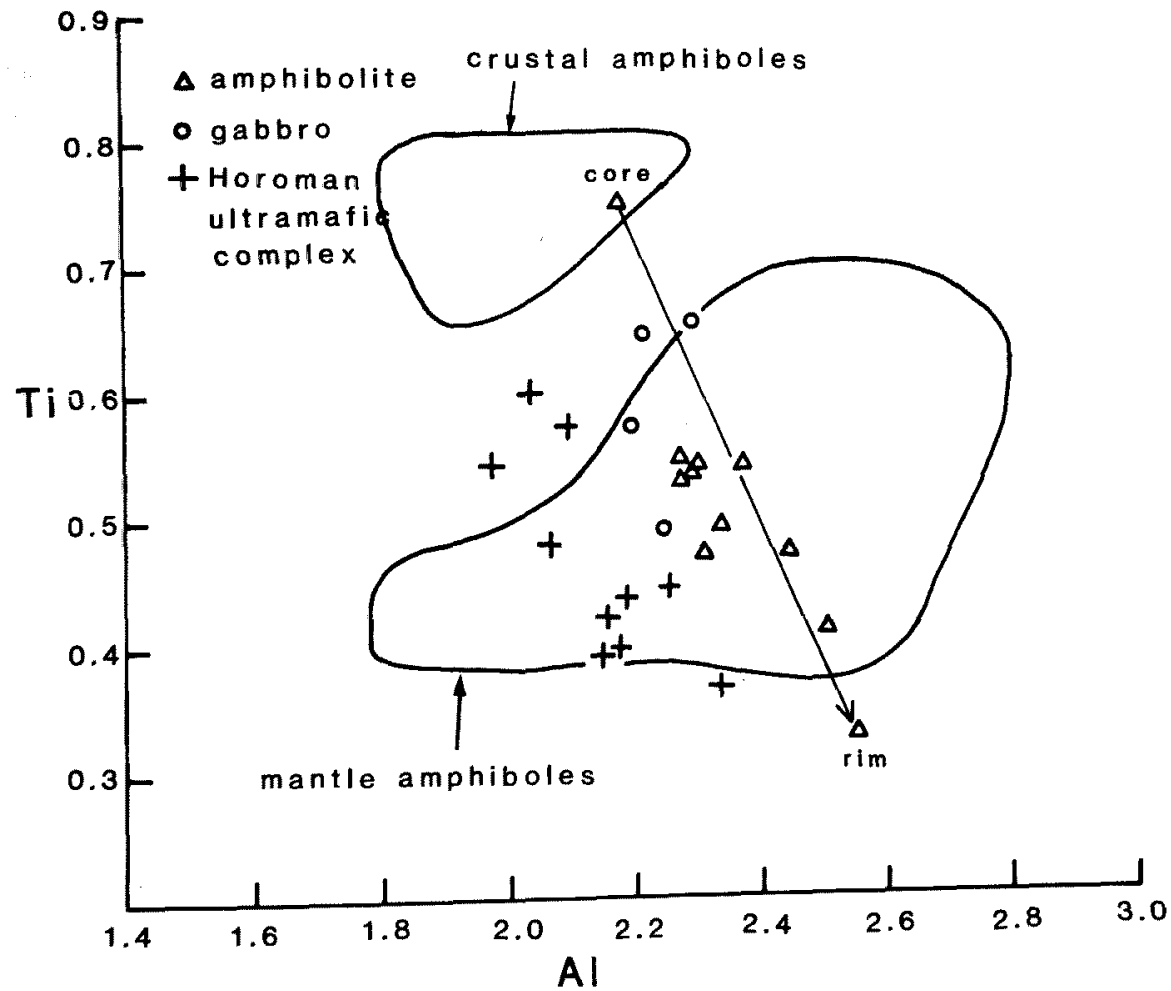

Fig. 6. Ti vs. Al diagram for amphiboles. Data of the Horoman ultramafic complex are from Niida (1984). Fields of mantle and crustal amphiboles are from Gamble and Kyle (1987). 
mantle amphiboles.

Fig. 7 shows the pyroxene compositions plotted on the quadrilateral diagram. Fig. 8 is the plot of $\mathrm{Al}^{\mathrm{vI}}$ versus $\mathrm{Al}^{\text {Iv }}$ for clinopyroxenes from the gabbro crust and the host peridotite. The diagram of $\mathrm{mg}=\mathrm{Mg} /(\mathrm{Mg}+\mathrm{Fe})$ versus distance from the contact between the gabbro and the peridotite is given in Fig. 9. Clinopyroxenes in the gabbro crust are rich in $\mathrm{Al}_{2} \mathrm{O}_{3}$ (max. $6.5 \mathrm{wt} \%$ ) and $\mathrm{TiO}_{2}$ (max. $2 \mathrm{wt} \%$ ), and exsolve orthopyroxene lamellae. Clinopyroxenes in the gabbro crust have chemical characteristics similar to those from xenoliths in basalts (Aoki and Shiba, 1973) (Fig. 8). Al, Ti and Fe contents of clinopyroxenes in the gabbro crust decrease toward the peridotite (Fig. 9). In the host peridotite, $\mathrm{Mg}$ contents of clinopyroxenes decrease toward the gabbro crust (Fig.9). Clinopyroxenes in the peridotite are rich in $\mathrm{Al}_{2} \mathrm{O}_{3}$ (max. $5.9 \mathrm{wt} \%$ ) and $\mathrm{Cr}_{2} \mathrm{O}_{3}$ (max. $1.0 \mathrm{wt} \%$ ) and poor in $\mathrm{TiO}_{2}$ (max. $0.7 \mathrm{wt} \%$ ). $\mathrm{CaO}, \mathrm{Al}_{2} \mathrm{O}_{3}$ and $\mathrm{TiO}_{2}$ contents of orthopyroxenes in the host peridotite are less than $1.14 \mathrm{wt} \%, 3 \mathrm{wt} \%$ and $0.2 \mathrm{wt} \%$, respectively. $\mathrm{Mg}$ contents of orthopyroxenes decrease toward the gabbro

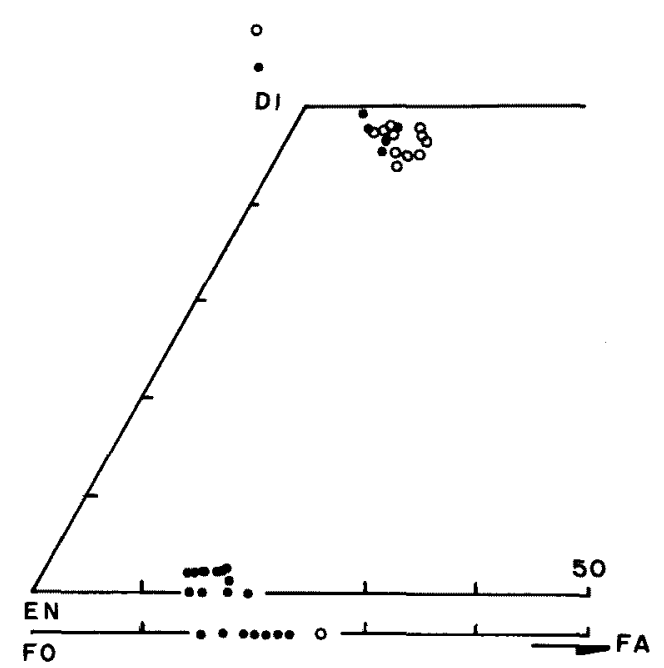

Fig.7. Quadrilateral diagram for pyroxenes and Fo contents of olivines. Abbreviations are the same as Fig. 5.

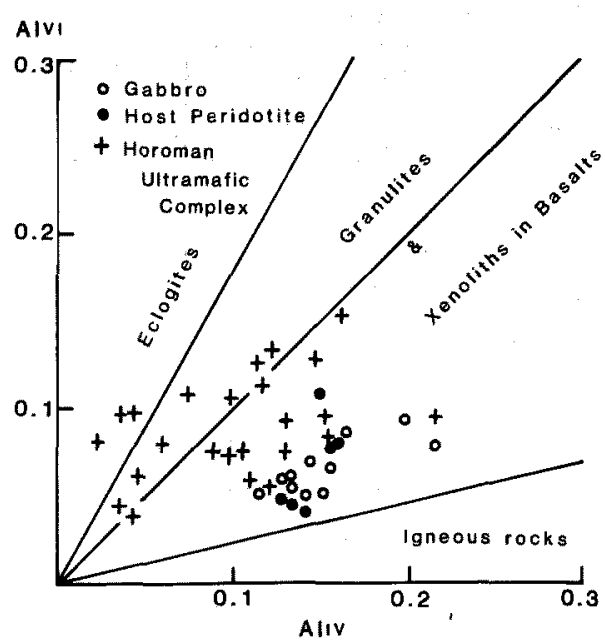

Fig. 8. $\mathrm{Al}^{\mathrm{vl}}$ vs. $\mathrm{Al}^{\mathrm{IV}}$ diagram for clinopyroxenes. Field boundaries are from Aoki and Shiba (1973).

crust (Fig. 9).

Fig. 7 and 9 show chemical compositions of olivines in the peridotite and the gabbro crust. $\mathrm{Mg}$ contents of olivines in the peridotite successively decrease toward the gabbro crust. An olivine in the gabbro crust is iron-rich ( $\mathrm{mg}=$ 0.74). Chemical variation of spinels in the host peridotite is illustrated in Fig. 9. $\mathrm{Mg} / \mathrm{Mg}+\mathrm{Fe}$ ratios of spinels also decrease toward the gabbro crust from the peridotite in concordance with the decreasing of $\mathrm{Mg}$ contents in olivines and pyroxenes. Concentration gradients of $\mathrm{mg}$ in constituent minerals of the peridotites and the gabbro crust would be explained by the diffusion between them.

Fig. 10 shows chemical compositions of phlogopites in the amphibolite xenolith and the gabbro crust. Plagioclases in the amphibolite and the gabbro crust do not show any apparent zonal structure.

\section{REE Compositions}

Rare earth element (REE) contents were analysed by means of an Inductively Coupled Argon Plasma Emission Spectrometer (ICP). 


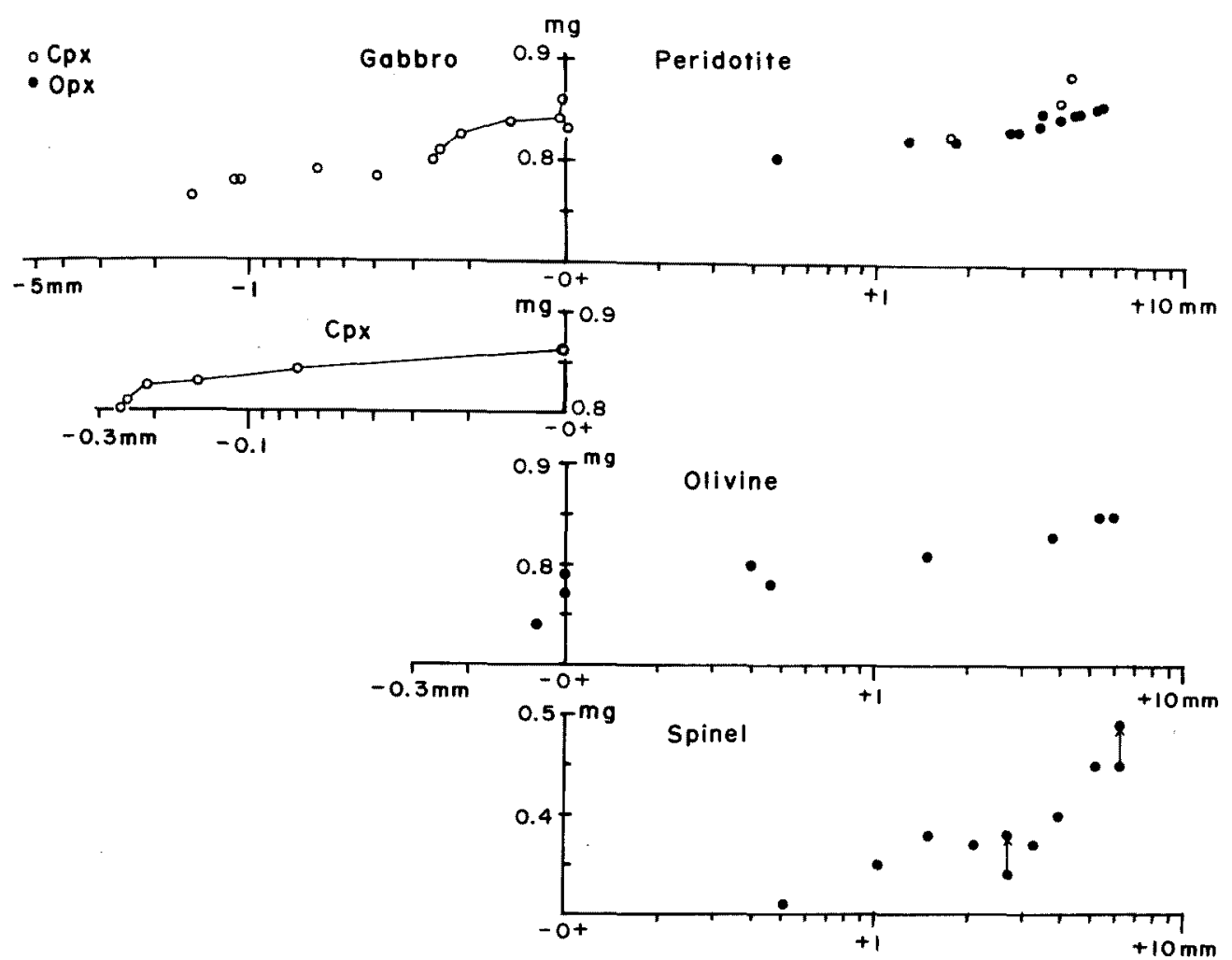

Fig. 9. $\mathrm{Mg}-\mathrm{Fe}$ diffusion profiles in the gabbro and the peridotite. Tie-lines represent a single grain. $\mathrm{mg}=\mathrm{Mg} /(\mathrm{Mg}+\mathrm{Fe})$

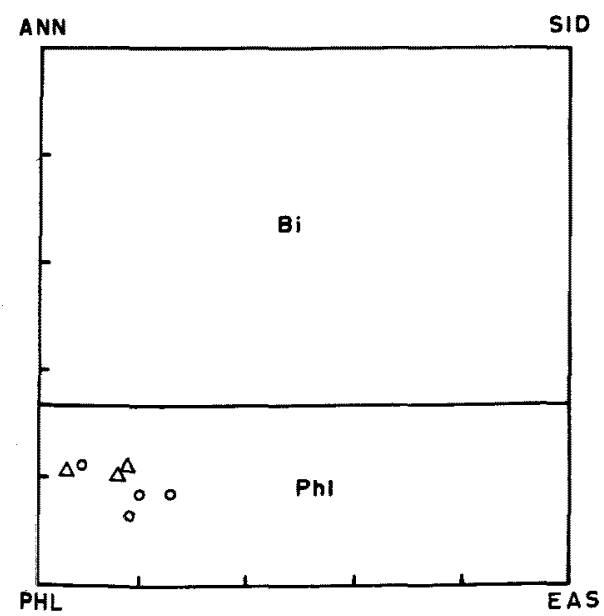

Fig. 10. Chemical variation of phlogopite. Abbreviations are the same as Fig. 5.
The analytical procedure was described by Tagiri and Fujinawa (1988). REE compositions of the amphibolite, the gabbro crust, Peridotites -1 and -2 are presented in Table 1 . Fig. 11 shows the REE normalized patterns on the basis of Leedy chondrite composition (Masuda et al., 1973). REE contents of the gabbro crust are higher than those of the amphibolite xenolith. However, they are depleted in both light and heavy REE, so that the two REE patterns show similar curves convex upwards. The similarity of the REE pattern may exclude an opinion that the gabbro crust originated from an extraneous melt intruding into the boundary between the peridotite and the amphibolite xenolith. On the contrary, the similar REE patterns allow an idea that the gabbro crust is a melting product of the am- 


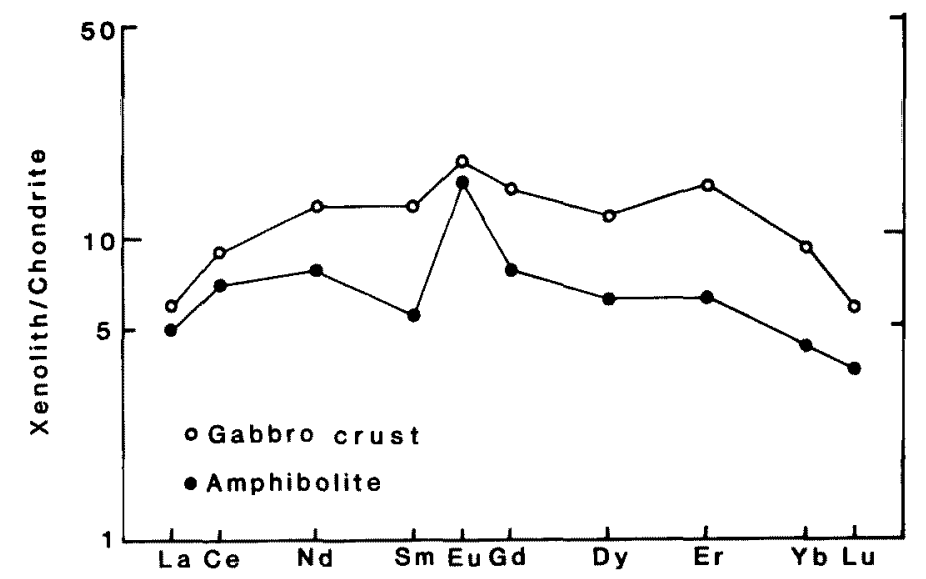

Fig. 11. REE normalized patterns of the amphibolite and the gabbro crust.

phibolite xenolith.

Both the amphibolite xenolith and the gabbro crust show positive Eu anomaly, though a larger anomaly is observed in the former. It is suggested that kaersutite-pargasite selectively melted into the gabbro crust. This is consis. tent with the enrichment of heavier REE preferentially contained by hornblende in the gabbro crust. A trace of some REE, for example Eu, Dy and $\mathrm{Yb}$, diffused into Peridotite-1 (Table 1).

\section{Discussion}

\section{Partial Melting of the Amphibolite Xenolith}

The mode of occurrence, major element chemistry and REE composition of the xenolith indicate that the amphibolite xenolith would have been melted partially or almost to form the gabbro crust, though melting textures are not observed in any crystal in the xenolith. Fig. 12 shows the bulk rock partition coefficients of major elements, REE and trace metals between the gabbro crust (=melt) and the amphibolite xenolith (=solid). The gabbro crust is depleted in $\mathrm{Na}, \mathrm{K}$ and $\mathrm{Al}$, and enriched with $\mathrm{Mg}, \mathrm{Ca}$ and $\mathrm{Sr}$, but $\mathrm{Si}, \mathrm{Ti}, \mathrm{V}, \mathrm{Mn}, \mathrm{Fe}$ and $\mathrm{Nb}$ are invariant. Heavy REE are highly concentrated in the gabbro crust except for Eu. The concentration of light REE is small in the gabbro crust.

Here, we consider that melting occurred in a closed system, and that the xenolith was composed of solid and melt parts. Assuming the REE partition equilibrium between solid and melt, the following equation holds (Masuda, 1979),

$$
\log (\mathrm{C} / \mathrm{Co})=(\mathrm{k}-1) \log \mathrm{Fw}_{\mathrm{w}}
$$

in which Co is the concentration of REE in the initial amphibolite xenolith, and $C$ is the concentration of REE in melt at a partial melting degree $(\mathrm{Fw})$. The coefficient, $\mathrm{k}$ is the bulk rock partition coefficient $\mathrm{C}^{\prime} / \mathrm{C}$, where $\mathrm{C}^{\prime}$ is the concentration of REE in solid. The $k$ is assumed to be constant in the partial melting process. Though the boundary between the amphibolite xenolith and the gabbro crust is gradual, we presume that their chemical compositions represent those of a solid and a melt in the xenolith.

If the melt did not migrate into the peridotite, the initial volume of the xenolith would have been the sum of present volumes of the amphibolite xenolith and the gabbro crust. When we adopt an elliptic disk of $205 \times 105 \times 35$ $\mathrm{mm}$ for the initial volume of xenolith based on the mode of occurrence, we get the volumetric 

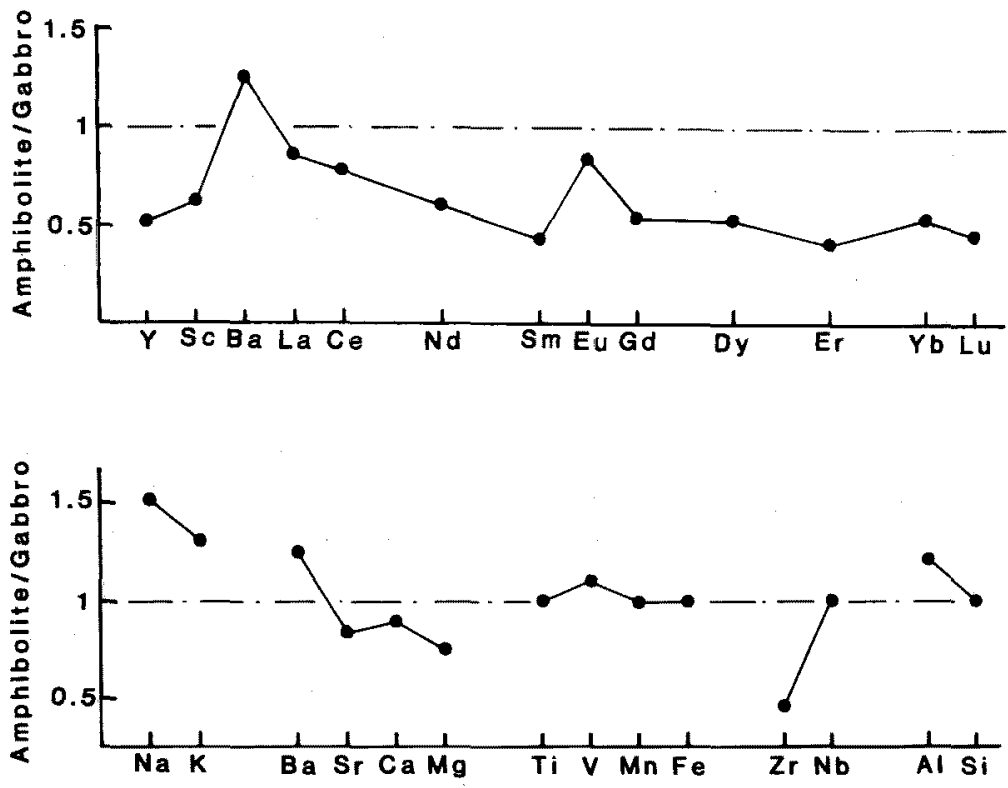

Fig. 12. Bulk rock partition coefficients.

ratio $1: 4$ for the gabbro crust to the amphibolite xenolith. Using this volumetric ratio, we can estimate a concentration of REE in the initial amphibolite xenolith before melting. Substituting all data of REE for the equation (1), we get $\mathrm{Fw}_{\mathrm{w}}=0.34-0.43$.

On the other hand, the bulk rock partition coefficients of major elements are about 1 (see Fig. 12), and $\mathrm{Mg} /(\mathrm{Mg}+\mathrm{Fe})$ of the gabbro crust is very similar to that of the amphibolite, which indicates a complete melting of the xenolith. As any migmatitic structure is not observed in the amphibolite xenolith, it is hardly to explain ca. $40 \%$ partial melting of the xenolith. It is concluded that the gabbro crust was produced by whole melting of the rim of the xenolith and some REE migrated from the interior of the xenolith to the melt.

Osanai et al. (1986) estimated $730^{\circ} \mathrm{C}$ and 6.5 $\mathrm{kb}$ for the P-T conditions of the granulite facies in the Main Zone, and concluded that these values correspond to the physical conditions at $23 \mathrm{~km}$ in depth of the lower crust. The peridotite body would have been in a deeper level. When we assume ca. $30 \mathrm{~km}$ in depth for the location of the peridotite, $960^{\circ} \mathrm{C}$ and $8.5 \mathrm{~kb}$ are given for the P-T conditions of the solid peridotite. These physical conditions are consistent with Niida's consideration $\left(850-1000^{\circ} \mathrm{C}\right.$ at Moho) (Niida, 1984). According to the experiments by Hariya et al. (1974), kaersutite and hornblende break down at $870^{\circ} \mathrm{C}$ and $920^{\circ} \mathrm{C}$, $8.5 \mathrm{~kb}$, respectively. An amphibolite including other minerals may begin to melt at a lower temperature, so that the amphibolite xenolith might receive enough heat to melt entirely.

\section{$M g-F e$ Diffusion between the Gabbro Crust and} the Peridotite

Fig. 9 shows the $\mathrm{Mg}-\mathrm{Fe}$ diffusion patterns of constituent minerals in the gabbro crust and the peridotite. In polycrystalline natural rocks, $\mathrm{Mg}-\mathrm{Fe}$ transport may occur by volume diffusion and boundary diffusion (Manning, 1974). The interface of the present case is the boundary between the gabbro crust and the peridotite. When the diffusion coefficient is known, we can estimate the heating duration or 
a mean path of transport based on the following equation ;

$$
\text { Mean path of transport }=\sqrt{2 \mathrm{Dt}}
$$

$$
\text { (Miyashiro, 1964). }
$$

Here, $\mathrm{D}$ and $\mathrm{t}$ are diffusion coefficient and time, respectively. Misener (1974) determined interdiffusion coefficients of $\mathrm{Mg}$ and $\mathrm{Fe}$ in olivine $(\mathrm{Fol} 0-80)$ at $900-1100^{\circ} \mathrm{C}$, and $1 \mathrm{~atm}-35$ $\mathrm{kb}$. From his experiments, we adopt an interdiffusion coefficient of Fo80, ca. 10E-15 $\mathrm{cm}^{2} / \mathrm{sec}$ at $900^{\circ} \mathrm{C}$ and $10 \mathrm{~kb}$. A mean path of transport in peridotite is supposed to be $1 \mathrm{~cm}$ from the interface, though it is less than $0.5 \mathrm{~mm}$ in the gabbro crust. Then, we obtain ca. $20 \mathrm{My}$ for a heating duration of the xenolith at $900^{\circ} \mathrm{C}$. A diffusion coefficient of $\mathrm{Mg}-\mathrm{Fe}$ in spinel is ca. $10 \mathrm{E}-11 \mathrm{~cm}^{2} / \mathrm{sec}$ at $1200^{\circ} \mathrm{C}$ and $1 \mathrm{~atm}$ (Lehmann, 1983). As it is still unknown at $900^{\circ} \mathrm{C}, 10 \mathrm{~kb}$, we cannot estimate any heating duration from spinel composition.

The interdiffusion coefficient must be extremely small compared to the apparent diffusion coefficient in natural rocks, because the interdiffusion coefficient was determined in the diffusion experiment between single crys. tals. In the diffusion experiment of ${ }^{18} \mathrm{O}$ in albite (Giletti et al., 1978), the coefficient in powder material is larger by the four order of magnitude than that in a single crystal. In the grain boundary diffusion process, the diffusion coefficient in polycrystalline olivine may increase by the four order of magnitude. When we adopt the larger value of the coefficient, the heating duration decreases by the two order of magnitude. The heating duration at $900^{\circ} \mathrm{C}, 0.2 \mathrm{My}$, is very short for the intrusion of hot solid peridotite. For example, a cooling rate of the Glen Dessary syenite from ca. $1000^{\circ} \mathrm{C}$ to $\mathrm{ca} .700^{\circ} \mathrm{C}$ was estimated to be ca. $30^{\circ} / \mathrm{My}$ by Cliff (1985). This rapid increase of temperature by the intrusion of the peridotite mass may cause the lower part of the Main
Zone to melt partially.

Acknowledgements : A part of the expense of this study was supported by the Scientific Grant-in-Aid from the Ministry of Education, Japan (No. 59430011, Prof. M. Hashimoto; No.60121005, 62103006, Prof. T. Iiyama). We acknowledge Prof. T. Iiyama of Chiba University, Prof. S. Banno of Kyoto University and Prof. H. Onuki of Hirosaki University for their discussions and encouragements, Prof. James Haratani, Prof. M. Hashimoto of Ibaraki University and Prof. M. Toriumi of University of Tokyo for their critical reading of the manuscript.

\section{References}

Aoki, K. and Shiba, I. (1973), Pyroxene from lherzolite inclusions of Itinome-gata, Japan Lithos, 6, 41-51.

Cliff, H.A. (1985), Isotopic dating in metamorphic belts. J. Geol. Soc. London, 142, 97-110.

Gamble, J.A. and Kyle, P. (1987), The origins of glass and amphibole in spinel-wehrlite xenoliths from Foster Crater, McMurdo Vol canic Group, Antarctica. J. Petrol., 28, 755779.

Giletti, B.J., Semet, M.P. and Yund, R.A. (1978) Studies in diffusion III : Oxygen in feldspars An ion microprobe determination. Geochim Cosmochim. Acta, 42, 45-57.

Hariya, Y., Oba. T. and Terada, S. (1974), Stability relation of some hydro-silicate minerals at high pressure. In Proceedings of the 4 th International Conference on High Pressure, Kyoto, 206-210.

Komatsu, S., Miyashita, S., Maeda, J., Osanai, Y., Toyoshima, T., Motoyoshi, Y. and Arita, K. (1982), Petrological constitution of the continental type crust upthrust in the Hidaka Belt, Hokkaido. J. Japan. Assoc. Min. Petr. Econ. Geol., Spec. Paper. 3, 220-230.

Kontani, Y. (1978), Geological study of the Hidaka Supergroup distributed on the east side of the Hidaka metamorphic belt (Part I)-Stratigraphy and geological structure. $J$. Geol. Soc. Japan, 8, 1-14.

Leake, B.E. (1978), Nomenclature of amphiboles Am. Mineral., 63, 1023-1052. 
Lehmann, J. (1983), Diffusion between olivine and spinel: application to geothermometry. Earth Planet. Sci. Lett. 64, 123-138.

Manning, J.R. (1974), Diffusion kinetics and mechanism in simple crystals. In Geochemical Transport and Kinetics (Hofmann, A.W., Giletti, B.J., Yorder, Jr. H.S. and Yund, R.A., Eds.). Carnegie Institution of Washington, Publication 634, 3-13.

Masuda, A. (1979), Variety of igneous rocks based on the REE geochemistry. In Iwanami KozaEarth Science 4, Earth's Materials III (Matsui, Y. and Banno, S., Eds.). Iwanami, Tokyo, 241264.

Masuda, A., Nakamura, N. and Tanaka, T. (1973), Fine structures of mutually normalized rareearth patterns of chondrites. Geochim. Cosmochim. Acta. 37, 239-248.

Misener, D.J. (1974), Cationic diffusion in olivine to $1400^{\circ} \mathrm{C}$ and $35 \mathrm{Kbar}$. In Geochemical Transport and Kinetics (Hofmann, A.W., Giletti, B. J, Yoder, Jr. H.S. and Yund, R.A., Eds.). Carnegie Institution of Washington, Publication $634,117-128$.

Miyashiro, A. (1964). Metamorphic Rocks and
Metamorphic Belt. Iwanami, Tokyo, pp. 458.

Miyashita, S. (1983), Reconstruction of the ophiolite succession in the western zone of the Hidaka Metamorphic Belt, Hokkaido. J. Geol. Soc. Japan, 89, 69-86.

Niida, K. (1984), Petrology of the Horoman ultramafic rocks in the Hidaka Metamorphic Belt, Hokkaido, Japan. J. Fac. Sci. Hokkaido Univ. Ser. IV, 21, 197-250.

Osanai, Y. (1985), Geology and metamorphic zon ing of the Main Zone of the Hidaka Metamorphic Belt in the Shizunai river region, Hokkaido. J. Geol. Soc. Japan, 91, 259-278.

Osanai, Y., Arita, K. and Bamba, M. (1986), P-T conditions of granulite-facies rocks from the Hidaka Metamorphic Belt, Hokkaido, Japan. J. Geol. Soc. Japan, 92, 793-808.

Shiba, M. (1988), Metamorphic evolution of the southern part of the Hidaka belt, Hokkaido, Japan. J. Metamorph. Geol., 6, 273-296.

Tagiri, M. and Fujinawa, A. (1988), Chemical analysis of REE and trace metals in GSJ rock reference samples by ICP. J. Min. Petr. Econ. Geol, 83, 102-106.

\title{
北海道日高変成帯のかんらん岩体中に包有される 角閃岩捕獲岩の部分溶融
}

\author{
田切美智雄・鈴木 英雄・鈴木 研司 \\ 稲沢 智昭・局㱦 一則・柴正敏
}

日高変成带ニカンベッかんらん岩体中に細粒の角閃岩捕獲岩を見出した。角閃岩はガブロの薄層に囲ま れて，かんらん岩体の層構造を切るよらに捕獲されている。角閃岩はケルスート閃石一パー゙ス閃石十斜長 石十イルメナイト，ガブロは単斜輝石十ケルスート閃石一パーガス閃石十斜長石十イルメナイトを主とす

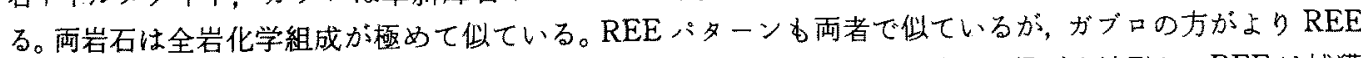
に富んでいる。これらの㛟討から，角閃岩はかんらん岩体に捕獲された時その縁が全溶融し，REEは捕獲

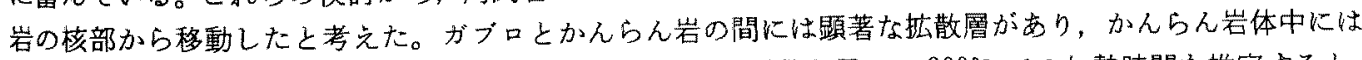

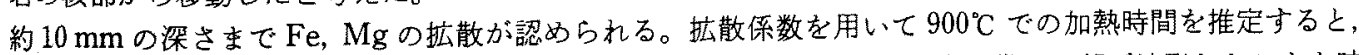
約 $0.2 \mathrm{My}$ となる。この結果は, 熱いか九らん岩体の迸入によって，日高変成带の下部が溶融したことを暗 示する。 